\title{
NITRATE REDUCTASE ASSAY USING SODIUM NITRATE FOR RAPID DETECTION OF MULTIDRUG RESISTANT TUBERCULOSIS
}

\author{
Maíra Bidart Macedo ${ }^{1}$, Andrea Von Groll ${ }^{{ }^{*}}$, Krista Fissette ${ }^{2}$, Juan Carlos Palomino ${ }^{2}$, Pedro Eduardo Almeida da Silva ${ }^{1}$, \\ Anandi Martin ${ }^{2}$
}

${ }^{1}$ Laboratório de Micobactérias, Faculdade de Medicina, Universidade Federal do Rio Grande, Rio Grande, RS, Brasil;

${ }^{2}$ Mycobacteriology Unit, Institute of Tropical Medicine, Nationalestraat, 155, Antwerp, Belgium.

Submitted: August 21, 2011; Approved: June 07, 2012.

\begin{abstract}
We validated the nitrate reductase assay (NRA) for the detection of multidrug-resistant Mycobacterium tuberculosis (MDR-TB) using sodium nitrate $\left(\mathrm{NaNO}_{3}\right)$ in replacement of potassium nitrate $\left(\mathrm{KNO}_{3}\right)$ as nitrate source. $\mathrm{NaNO}_{3}$ is cheaper than $\mathrm{KNO}_{3}$ and has no restriction on use which facilitates the implementation of NRA to detect MDR-TB.
\end{abstract}

Key words: nitrate reductase assay; tuberculosis; multidrug resistant, sodium nitrate

Tuberculosis (TB) remains as a serious health problem worldwide. In 2008, 9.4 million new cases of the disease were reported (8). Besides, there were approximately 400,000 new annual cases of TB caused by multidrug resistant (MDR) strains, defined as resistant to at least isoniazid (INH) and rifampicin (RIF) (8). Rapid detection of drug resistance is an urgent priority to identify patients who are not responding to the standard treatment and to avoid the transmission of resistant strains (4). Recently, the WHO endorsed new noncommercial drug susceptibility testing methods for the detection of MDR-TB patients, and among them, the nitrate reductase assay (NRA). NRA is based on the capacity of $M$. tuberculosis to reduce nitrate to nitrite, which is easily detected in a colored reaction (5). NRA was initially standardized using potassium nitrate $\left(\mathrm{KNO}_{3}\right)$ (1) as nitrate source, but due to its higher cost and restriction of use in several countries, some authors have used sodium nitrate $\left(\mathrm{NaNO}_{3}\right)$ as nitrate source (3, $6,7)$. However, there is no study comparing the accuracy of NRA using $\mathrm{NaNO}_{3}$ in replacement of $\mathrm{KNO}_{3}$. In this study, we evaluated the use of the $\mathrm{NaNO}_{3}$ in the NRA test to detect MDR-TB in comparison with $\mathrm{KNO}_{3}$ and results were compared to those obtained with the conventional proportion method (PM) performed on Löwenstein-Jensen (LJ) medium.

One-hundred and six M. tuberculosis strains belonging to the collection of the Institute of Tropical Medicine of Antwerp, Belgium, were studied. The strains were cultured in LJ medium and incubated at $37^{\circ} \mathrm{C}$ for three weeks. The PM was performed according to Canetti et al (2), using critical concentrations of $0.2 \mu \mathrm{g} / \mathrm{mL}$ for INH and $40 \mu \mathrm{g} / \mathrm{mL}$ for RIF. The NRA was performed according to the previously reported methodology

\footnotetext{
*Corresponding Author. Mailing address: Laboratório de Micobactérias e Biologia Molecular - Faculdade de Medicina - Área Acadêmica -Universidade Federal do Rio Grande (FURG) - Rua General Osório,snº - Centro - Rio Grande, RS - Brasil - ZIP: 96200-400.; Tel.: +55 53 3233 0318.; E-mail: avongrol@hotmail.com
} 
(1). The NRA was carried out in LJ medium incorporating 1.0 $\mathrm{mg} / \mathrm{mL}$ of $\mathrm{NaNO}_{3}$ or $\mathrm{KNO}_{3}$. The critical concentration of INH and RIF were the same used in the PM.

Table 1 shows the sensitivity and specificity obtained with the NRA using $\mathrm{NaNO}_{3}$ or $\mathrm{KNO}_{3}$ compared to the PM. Drug susceptibility testing for RIF showed a sensitivity of $95 \%$ with $\mathrm{KNO}_{3}$ and $96 \%$ with $\mathrm{NaNO}_{3}$. Specificity was $97 \%$ for both nitrate sources. For INH the sensitivity was $97 \%$ with $\mathrm{KNO}_{3}$ and $99 \%$ with $\mathrm{NaNO}_{3}$ while the specificity was $96 \%$ and $93 \%$, respectively.

Out of the 106 strains tested, results were available after 10 days for 101 strains $(95.3 \%)$ using $\mathrm{KNO}_{3}$ and for 104 strains (98.1\%) using $\mathrm{NaNO}_{3}$. All strains were positive after 14 days with both reagents.

This study showed that the NRA gave similar results using $\mathrm{KNO}_{3}$ or $\mathrm{NaNO}_{3}$, as nitrate source. NRA using $\mathrm{NaNO}_{3}$ showed high sensitivity and specificity for RIF (96\% and 97\%, respectively) and INH (99\% and 93\%, respectively). These results are in agreement with previous studies presented in a meta-analysis that evaluated the accuracy of the NRA for the detection of MDR-TB. According to that meta-analysis most of the studies that applied NRA to test M. tuberculosis isolates reported a sensitivity and specificity $>94 \%$ for RIF and $>92 \%$ for INH (5). Another important finding in the present study was that $98 \%$ of the strains showed results in 10 days with NRA using $\mathrm{NaNO}_{3}$. This percentage was higher than that obtained using $\mathrm{KNO}_{3}$ and also in a previous study where $87 \%$ of the strains gave results in 10 days (1).

$\mathrm{KNO}_{3}$ is considered as a class of "explosive" and consequently difficult to obtain in some countries such as Brazil. Additionally, $\mathrm{NaNO}_{3}$ is cheaper than $\mathrm{KNO}_{3}$ and has no restriction of use.

Taking into account the high sensitivity and specificity obtained using $\mathrm{NaNO}_{3}$ and the rapid availability of results with $98 \%$ of the strains in 10 days, our study validates the use of $\mathrm{NaNO}_{3}$ as the source of nitrate for NRA.

Table 1. Sensitivity and specificity of the NRA using $\mathrm{KNO}_{3}$ and $\mathrm{NaNO}_{3}$ compared to the PM method.

\begin{tabular}{|c|c|c|c|c|c|c|c|c|c|}
\hline \multirow[b]{2}{*}{ Drug } & \multirow[b]{2}{*}{$\mathbf{P M}$} & \multicolumn{4}{|c|}{$\mathrm{NRA}_{-\mathrm{KNO}_{3}}$} & \multicolumn{4}{|c|}{$\mathrm{NRA}_{-N a N O}$} \\
\hline & & $\begin{array}{c}\mathbf{R} \\
\text { (n) }\end{array}$ & $\begin{array}{c}\text { S } \\
\text { (n) }\end{array}$ & Sensitivity (\%) & Specificity (\%) & $\begin{array}{c}\mathbf{R} \\
\text { (n) }\end{array}$ & $\begin{array}{c}\mathrm{S} \\
(\mathrm{n})\end{array}$ & Sensitivity (\%) & Specificity (\%) \\
\hline RIF & $\begin{array}{l}\mathrm{R} \\
\mathrm{S}\end{array}$ & $\begin{array}{c}72 \\
1\end{array}$ & $\begin{array}{c}4 \\
29\end{array}$ & 95 & 97 & $\begin{array}{c}73 \\
1\end{array}$ & $\begin{array}{c}3 \\
29\end{array}$ & 96 & 97 \\
\hline INH & $\begin{array}{l}\mathrm{R} \\
\mathrm{S}\end{array}$ & $\begin{array}{c}76 \\
1\end{array}$ & $\begin{array}{c}2 \\
27\end{array}$ & 97 & 96 & $\begin{array}{c}77 \\
2\end{array}$ & $\begin{array}{c}1 \\
26\end{array}$ & 99 & 93 \\
\hline
\end{tabular}

$\overline{\mathrm{R}}=$ resistant; $\mathrm{S}=$ susceptible; $\mathrm{PM}=$ proportion method

\section{ACKNOWLEDGEMENTS}

We thank the comments and suggestions of Dr. Maria Alice Telles and Dr. Lucia Barrera for the performance of this study.

\section{REFERENCES}

1. Ängeby, K.A.K.; Klintz, L.; Hoffner, S.E. (2002). Rapid and Inexpensive Drug Susceptibility Testing of Mycobacterium tuberculosis with a Nitrate Reductase Assay. J Clin Microbiol. 40, 553-555.
2. Canetti, G.; Froman, S.; Grosset, J.; Hauduroy, P.; Langerova, M.; Mahler, H.T.; Meissner, G.; Mitchison, D.A.; Sula, L. (1963). Mycobacteria: laboratory methods for testing drug sensitivity and resistance. Bull. World Health Organ. 29, 565- 578.

3. Kumar, M.; Khan, I.A.; Verma, V.; Kalyan, N.; Qazi, G.N. (2005). Rapid, inexpensive MIC determination of Mycobacterium tuberculosis isolates by using microplate nitrate reductase assay. Diagn. Microbiol. Infect. Dis. 53, 121-124.

4. Lemus, D.; Martin, A.; Montoro, E.; Portaels, F.; Palomino, J.C. (2004). Rapid alternative methods for detection of rifampicin resistance in Mycobacterium tuberculosis. J Antimicrob Chem. 54,130-133.

5. Martin, A.; Panaiotov, S.; Portaels, F.; Hoffner, S.; Palomino, J.C.; Angeby, K. (2008). The nitrate reductase assay for the rapid detection of 
isoniazid and rifampicin resistance in mycobacterium tuberculosis: a systematic review and meta-analysis. J. Antimicrob Chem. 62, 56-64.

6. Sanchotene, K.O.; Von Groll, A.; Ramos, D.F.; Scholante, A.B.; Honscha, G.; Valença, M.; Scaini, C.J.; Silva, P.E.A. (2008). Comparative evaluation of the nitratase reductase assay and the resazurin microtitre assay for drug susceptibility testing of Mycobacterium tuberculosis against first line anti-tuberculosis drugs. Braz. J. Microbiol.
$39,16-20$.

7. Solis, L.A.; Shin, S.S.; Han, L.L.; Lanos, F.; Stowell, M.; Sloutsky, A. (2005). Validation of a rapid method for detection of Mycobacterium tuberculosis resistance to isoniazid and rifampin in Lima, Peru. Int. J. Tuberc. Lung Dis. 9, 760-764.

8. World Health Organization. Global tuberculosis control report 2010. HTTP://www.who.int. 